\title{
INTRODUCING A MODEL OF ORGANIZATIONAL ENVY MANAGEMENT AMONG UNIVERSITY FACULTY MEMBERS; A MIXED RESEARCH APPROACH
}

\section{Zarin Daneshvar Maris ${ }^{21}$, Reza Yousefi saidabadi ${ }^{22}$, Kiumars Niazazari ${ }^{23}$}

\begin{abstract}
The present study aimed at offering a model of organizational envy management among faculty members of Islamic Azad Universities of East Azarbaijan Province. A mixed method through involving qualitative data and then quantitative data emphasizing on quantitative analysis. Population of the study was the entire faculty members with associate or higher degree in the educational year of 2014-2015. In the qualitative stage 20 individuals (experts) were selected to design the primary model and questionnaire, and to fit the model 316 faculty members were selected. In the qualitative section it was specified that influential variables on envy management in faculty members are health organizational climate, spiritual leadership, effective communication, job satisfaction and professional development of professors and approved, as well in the quantitative section findings showed that there is a significant relationship between effective variables so that in indirect analysis of effect of organizational climate on envy management, the variable of spiritual leadership via the variable of effective communication had little effect on envy management than variables of professional development and job satisfaction. It is concluded that university managers should provide conditions and backgrounds of envy management in the universities and enable professors for more effective roles without envy in the scientific climate of university to achieve in educational, research and servicing efficiency.
\end{abstract}

KEY WORDS: environmental envy management, organizational climate, spiritual leadership, communication, job satisfaction, workers' development

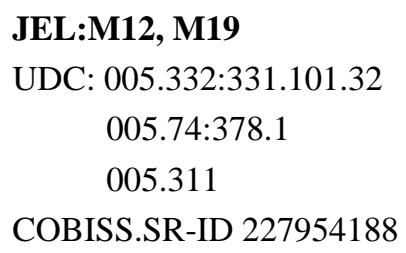

\footnotetext{
${ }^{21}$ Islamic azad university of Sari,Iran, e-mail:daneshvar88@yahoo.com

${ }^{22}$ Corresponding author, Islamic azad university of Sari,Iran,e-mail: ruosefi@yahoo.com,

${ }^{23}$ Islamic azad university of Sari,Iran,e-mail: nniazazari@gmail.com,
} 


\section{INTRODUCTION}

Nowadays, one problem inside administrative organizations including universities and educational centers is the issue of envy among employees so that has reduced motivation of working and attempts of employees. Since it is an important issue, some studies emphasized on envy management and indicated that it is required to be studied in this Iran. Envy employees have a little commitment to organization and consequently have a direct and negative impact on organizational performance. Individuals having such problems have a little attention to future, because in their views past and present are not different from each other (Fard, 2011). This destructive phenomenon in higher education should be managed to see developing human resources in higher education with the least level of envy.

With such assumptions, the present study tries to find a proper model of envy management in Islamic Azad Universities of East Azarbaijan province, to specify the dimensions and components of the model in order to measure the share of each component in envy management. Therefore, such assumptions for introducing and offering a model can help faculty members, professors, and university managers to concern about this issue by offering more precise programs to use envy management for reaching at organizational purposes and improving the quality of university services.

\section{Statement of the problem}

Currently, more than any other times we need an active, lively and organized working environment in the system of higher education, an environment that the entire needs of human being are introduced besides their complexity with calm and relatively free spaces, enabling people to be active without harsh and fragile obstacles. It means that a healthy climate provides the grounds for access to individuals' needs that causes a type of hope, joy, and sense of prosperity (Mirkamali, 1999). Because in the current competitive environment anxiety and attempts of organizations is to survive and develop them entirely that in line with this great purpose managers are going to introduce and optimally benefit resources and capitals which acquiring them required costs and troubles. The winner of this field is managers which utilize the stated capitals effectively and productively (Hodson, 2002). In spite of the effective role of efficient human capital in organizations, envy is a significant structure in the working environment which has a powerful effect on human capital in organizations (Vecchio, 2000). More importantly, when the sense of envy is repeated, it result in enmity among people and their intention for friendship decreases (Salovey, Rodin, 1984) and if this sense of envy increases, individuals may try to damage each other (Cohen-Charash, Mueller, 2007) and unethical behaviors among them increased causing them to have no intention for helping each other (Gino, Pierce, 2010). Also, if envy occurs in members, controlling or hiding it would be difficult and simply it will be possible to manage and change this sense (Parrott, 1991). Because, when individuals are close to each other physically and mentally, social comparisons and envy increases (Tesser, 1998). Researchers had not performed a considerable study in this way and this requires a number of studies. But some researchers such as Tai et al., (2012) believe that envy may result in negative or positive behaviors, since envy individual is seeking to attain the situation of the other person and until shows no innovation or creativity, there would be no happening, but when the chance of privilege or fitting expressed, enviers hardly try to attain opportunities. In such a way those ignorant and megalomania people grab the chances from deserved 
individuals and since they are not on the right path, they cannot benefit the, (Golbaf, 1996). Immediately, after specifying a proper and deserved performance by deserved workers who grew without closeness to authorities, the market of slandering, backbiting and accusation will be developed and employees will be invoked to destruct the modesty of deserved individuals and instead of trying to achieve their attempts will be consumed to destructing successful people to degrade them.

Besides some studies in Iran (Abedi et al., 2014; Khalifeh, 2012) and in foreign countries (Gökhan Özkoç, Çaliskan, 2014; Weltfreid, 2014; Erdila, Müceldili, 2014; Odle, 2014; Tai, 2012) about organizational envy and its consequences on organization is an issue that incited the present researcher to concern that in Iranian organizations spatially in educational institutions envy is not concerned and generally the role of organizational envy is neglected in many cases and its consequences is not contemplated. As well, looking at changing situations those newcomers in organizations are interested to be promoted in their position. It shows that individuals after being selected are targeted to other's envy and their working experience, family relationships and even their feed and closing are seriously criticized. For this reason, some managers after being selected in a job to prevent every event including weak performance or envy try to invite their relatives into the organization as employees to protect their privileges and position and dismantle the previous managers! Or some new managers question performance of previous managers and even neglect the positive aspects of their managing time.

Disrespecting designs and programs of previous employees and foregrounding the weaknesses, some deliveries of letters to the Audit Courts, interviews and calculations are envies that corrupted the proper competition or the manager and the rivals. University as a training institution is responsible for educating the future generation of society plays a significant role in development and promotion of societies. Therefore, with respect to increasing importance of them in society and the role of faculty members in the cultural texture of society, envy management is an important matter that needs to be concerned by university heads and managers of university departments.

\section{THEORETICAL FRAMEWORK OF THE STUDY}

\section{The concept and quiddity of envy}

According to definitions, envy is a well-known issue regarding interpersonal relationships that is seen in the form excitement. This concept, against other excitements is not understood from a facial sign or unique state. But, it is seen as a complex compound of unpleasant psychological condition such as sense of humility, injustice, and anger (Nandedkar, 2011). In all these cases the individual tries to hide his/her sensation.

Psychologically, envy is the result of comparing oneself to others. It is a negative sensation that individual finds his/her shortages. Enviers are suffering seeing others with happiness (Smith, Kim, 2007, p. 47). The sense of envy is a mixture of several emotions; the person can sense it and other are not able to perceive it (Nandedkar, 2011, p. 54). Also, envy is an indecent trait indicating a type of metal distress in people that can affect the positive and valuable features and destruct them entirely.

With understanding the concept of envy, the meaning of envy in organization should be examined and to see the extent in which employees are familiar with this concept. Employees' envy is mental, sensual, and behavioral pattern that is the result of lacking self-esteem or working relationship consequences (Vecchio, 1995). Envy is humanistic phenomenon highly 
existed in societies, organizations and human being (Foster, 1972, p. 165) that is leading in destructive results. The sense of envy might be related to increasing motivation for improving the self or changing motivations, that is mostly related to enmity and seeking misery for others (DelPriore et al.,2011). Salovey and Rodin (1984) believed that envy might occur for a sense of deprivation than others; more than one motivation to access what result in priority of one person to others which envier tries to have more privileges and benefits than others. People are usually envy of individuals which think they are similar. For example people are envy of individuals at the same age and similar gender (Salovey, Rodin,1984; Schaubroeck, Lam, 2004). On the other hand, individuals those similar to us are more threats to our self-esteem and others similar to us justify their prosperity (Heider, 1958) or, even, others similar to us follow this attitude that "I could be that" (Ben Zeev, 1992) and causes more cognitive self-evaluation. Generally, envy is an unpleasant sense that can be an unpleasant social comparison that a person is seeing a similar person is benefiting some conditions and wished for those conditions, but entirely in vein (Alicke, Zell, 2008). According to aforementioned studies envy means worry in a person after providing proper conditions for another person (Thai et al., 2012). Primary studies on behaviors of managers in 1950 and 1960s were done by psychologists. Recently, a changing in moods and individuals' behaviors to sensations is seen (Gfart et al, 2009). Researchers used Lazarous et al's (2001) list of discrete emotions (including anger, anxiety, fear, guilt, shame, sadness, jealousy, joy, pride, relief, hope, love, appreciation and affection) for perceiving the role of sensation on organizational conditions. Some considered envy as a significant structure in the working place which has a powerful impact on workers (Vecchio, 2000). Employees compare benefits and salaries via formal and unformal mechanisms and difference result in developing competition and envy among colleges (Erdil, Muceldili, 2014). In spite of the stated studies it should be seen the way this humanitarian phenomenon can be managed in organizations. Many variables can affect envy management and there are different theories to envy management including the theory of social interaction, Heider's balance and true unity of MacGregor purposes are exemplary.

\section{RELATED THEORIES TO ENVY MANAGEMENT}

The theory of social comparison emphasizes on this assumption that workers through comparing themselves with similar individuals evaluate their abilities (Festinger, 1945). This comparison can result in the two entirely different results. If the result of comparing the individual with others is proper, it result in acquiring and gaining identity and if it is not proper, then it results in destructing identity. Destructing identity it results in envy (Dafi et al., 2008). According to the Heider's theory of balance "the general form and source of envy" is intention for equalizing the rate of prosperity between person and other (person). The balance theory of Heider states that when individual see himself/herself at the same class with the other person, there is a strong intention for this belief that they should have equal prosperity, such pressure for equality might be strong to be considered as a justice nature or a force pressure and according to the theory of true unity of purposes, in one organization it is hopeful to provide a space resulting in one of the two following states:

A. Employees of organization (managers and subordinates) perceive their goals similar to organizational purposes.

B. If goals are not the same and they are different, individuals in organization individuals inside organizations see their goals achievable to achieve in organizational purposes. As a result, to the extent destinations and personal goals can be closer to organizational purposes, then organizational performance will be better and greater (Weltfried, 2014). 


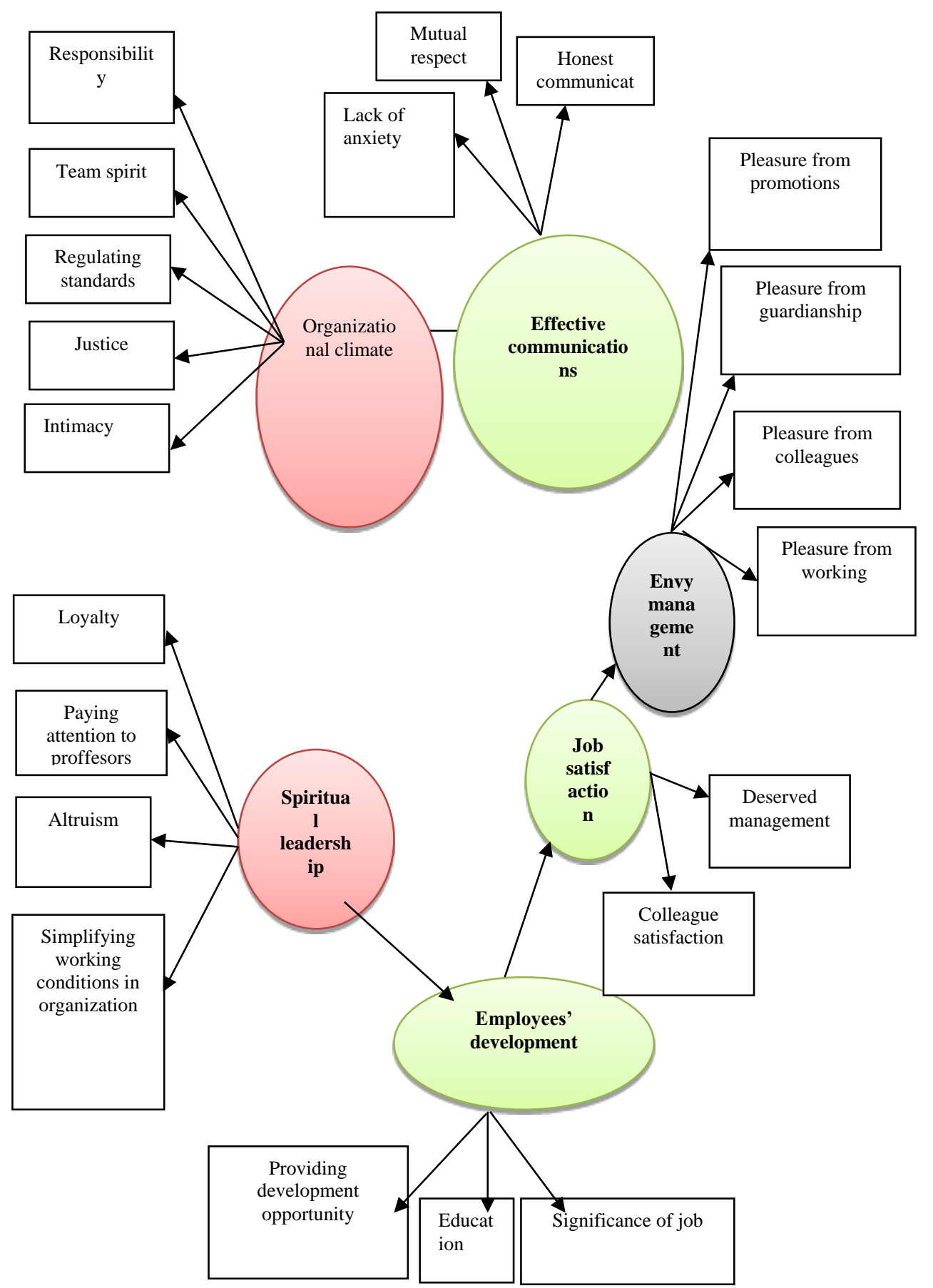

Figure 1: The primary model of the study on the basis of background and qualitative section 


\section{METHODOLOGY}

The present study aimed at analyzing organizational envy management among faculty members of Islamic Azad Universities of East Azarbaijan. Since the study used a mixed method of exploratory research (qualitative and quantitative); with respect to bases of data, the research entailed a mixed method that using mixed method and exploratory design was performed. This design was started by collecting and analyzing qualitative data and then the second stage was collecting and analyzing quantitative data. In the second stage the study is on the basis of the first stage or connecting to primary qualitative design (Ridoner, Newman, 2008, p. 32). In the qualitative section, the technique of Delfi was used for specifying variables and effective components, and in quantitative section after discovering variables and components of the primary research model they were fitted via structural equation modeling.

Population and sampling: there are two samples in this study that in qualitative section using purposeful sampling 20 individuals from faculty members with associate and higher level in the field of training sciences and management were used to discover dimensions and components of envy management. In the quantitative section using randomly sampling method and using Morgan (1970) table with 95\% confident, from among 685 faculty members (associate professor and higher) 316 individuals were selected as a randomly samples.

\section{Data collection instruments and specifying stability}

The instrument of this study was a researcher made questionnaire similar to Delfi technique (in 4 stages) that under variables such as professional development of professors using Cronbach's alfa was 0.774 , and other items including effective communications, healthy organizational climate, job satisfaction, spiritual leadership and envy management were $0.841,0.813,0.797,0.904$ and 0.864 , respectively, that were approved in the stage of formal and content validity.

\section{FINDINGS}

\section{Qualitative section:}

In the first period the list of dimensions and influential indexes on organizational envy management was offered to the first group to tell their ideas accordingly. As well, they wanted to add their ideas in the form of suggestions or modifying the index. In the second round the collected issues along with results of the first stage were offered to the second group to specify the importance of each dimension or index. The third round was along with the results of the first and second stage and in every stage the researcher performed necessary modifications on indexes and dimensions. Besides offering the mean of results to board of groups, finally in the fourth round the board of decision making agreed upon a unique idea. According to the final consensus of the boards, one of these variables with higher effect is healthy organizational climate that result in effective working relationships. 


\section{Healthy Organizational Climate}

Organizational climate is the measurable facade of culture and sensation of employees to environment which they are living. Healthy organizational climate helps creating motivation for workers and improving their spirit and involving individuals in decision making and increasing innovation and creativity in them as a resource of supplying employees' mental health (Dehdashti et al., 2013). Previous studies showed that organizational climate has a significant effect on worker's behavior and organizational results. But, unfortunately most of the organizations regarding organizational climate have no proper condition for working. Since, it is approved that policies, programs and financial conditions in organizations are not determining factors in creating a proper condition, but leaders of appropriate effective climate will be created that organizational employees are loyal to, and remove any obstacle on their ways. Appropriate organizational climate besides workers' responsibility (Hariri et al., 2013), team spirit (Vaziri et al., 2010), regulating standards (Sehdashti et al., 2012), organizational commitment, justice (Eskandari et al, 2010) and truthfulness and intimacy (Liman, 2003) occurs. In addition to healthy organizational climate university leadership is one adjusting agent of workers' envy especially members of the stated boards that spiritual leadership was presented according to statements of the most of members.

\section{Spiritual leadership}

Spiritual leadership that is founded on the basis of servicing philosophy is a main component of spiritual working environments. There are many suitable reasons for relationship between spirituality and management, spirituality affects managerial behavior and perspectives of working along with meaning by means of spirituality. The leadership methods of managers who have more intention toward spirituality were more effective than managers who have no tendency to spirituality (Starck et al., 2008). Currently the role of spirit managers is to motivate workers with applying spirit landscapes and providing cultural grounds according to humanistic values for workers to rear empowered workers with high productivity, commitment and motivation. Spiritual leadership emphasizes on the sense of purposefulness and meaningfulness in life and possibility of effective management of surrounding environment and ability of following internal beliefs and the sense of growth and self-perception. This theory is a motivating model of developed internalizing motivation that is founded on features like hope, belief, and altruism (Fernando et al., 2009). Spiritual leaders represent values including harmony, love, friendship, kindness, solidarity, trust and loyalty. In specifying the two stated variables above, the members of the board referred to gathering of effective information under the shadow of healthy organizational climate for the mediating role of spiritual leadership of university mangers.

\section{Effective communications}

Leader of organization with high emotional capability transmits his/her sensation to individuals and causes cooperation in the working team. The well team leaders know that with improving their relationships with others and creating a passionate and intimate climate increase the level of productivity. Accordingly they emphasize on strong and positive relationships in organizations, and establish mutual relationships with workers and offer them necessary 
information and approve their capacity to them and increase their ethical behaviors honestly in the public. These managers by thankfulness provide conditions and opportunities for growth of employees, their interfering in affaires, welcoming ideas and sensitivity to their personal intentions and express their respect to workers. Also, the same issue results in agreement and internal motivation of the entire university employees.

\section{Job satisfaction}

In a simple definition of job satisfaction we can say that this variable is a reference job variable that according to it, individual experiences emotions, cognitions and positive behaviors for their occupation which are hopeful. In more simple terms we can say that job satisfaction includes a positive emotional states that individual for doing the roles and occupational duties experiences them (Golparvar et al., 2011). High job satisfaction shows an organization that can be leaded properly (Robbins, 1999). Managers for three reasons should emphasize on workers' job satisfaction. At first, unsatisfied individuals that more than others are absent resign and leave working environment; second, workers satisfied with physical and mental health live longer; third, with increasing job satisfaction, commitment to work (organizational commitment) will be increased (Hosainei Hashemzadeh, 2010). Studies showed that organizational loyalty and job satisfaction have a proper relationship to organizational and job performance and negatively they are related to transactions and absence of workers (Haidari et al., 2013).

\section{Employees' development}

Employees development occurs in the result of job satisfaction besides other variables by members of the board better can share in employees envy management. Empowering employees refers to a process that manager helps employees to obtain the necessary ability for independent decision making. This process is influential not only in individual's performance, but also in their personality. Respecting employees' development, personal, professional and organizational development can be performed in developmental oriented organizations (Moradi, Saied Kalan, 2005). Avolio et al (2004) concluded that employees' development is related to spiritual leadership and causes commitment in individuals. As well, employees' professional development causes innovation and creativity (Shaemi Barzaki et al., 2013). Generally speaking, envy management in university for the effects of the entire variables will be formed and it is possible to involve the other variables that are not covered in this study.

\section{Quantitative section:}

For analyzing validity and sufficiency of data the index of KMO was used that the value of this index was $0.79 \%$. Therefore, the rate of samples is proper for using structural equations. Generally, the above value (close to 1) shows that factorial analysis is applicable for data. If this value is less than 0.5 , probably the result of factorial analysis would not be suitable for data. In approval factorial analysis, the coefficients between questions and research variables are standardized coefficient that shows measurement ability of each index in the research variable. This coefficient is between 0 and 1 and to the extent it is closer to 1, represents higher ability of the index in measuring the variable. Coefficients of the significant level for the variables of the model are as follows: 


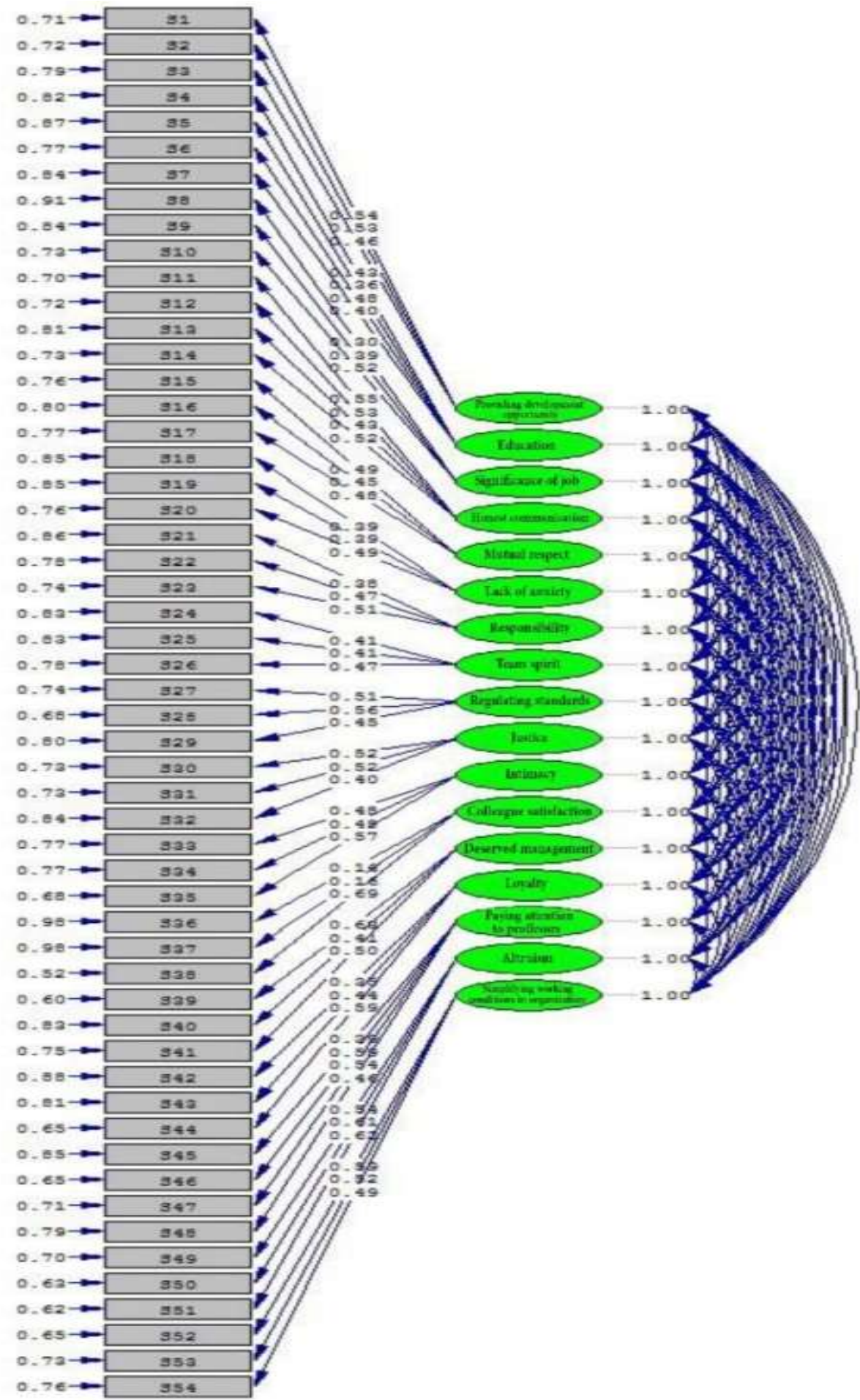

Figure 2: approval factorial analysis of influential variables on envy management 


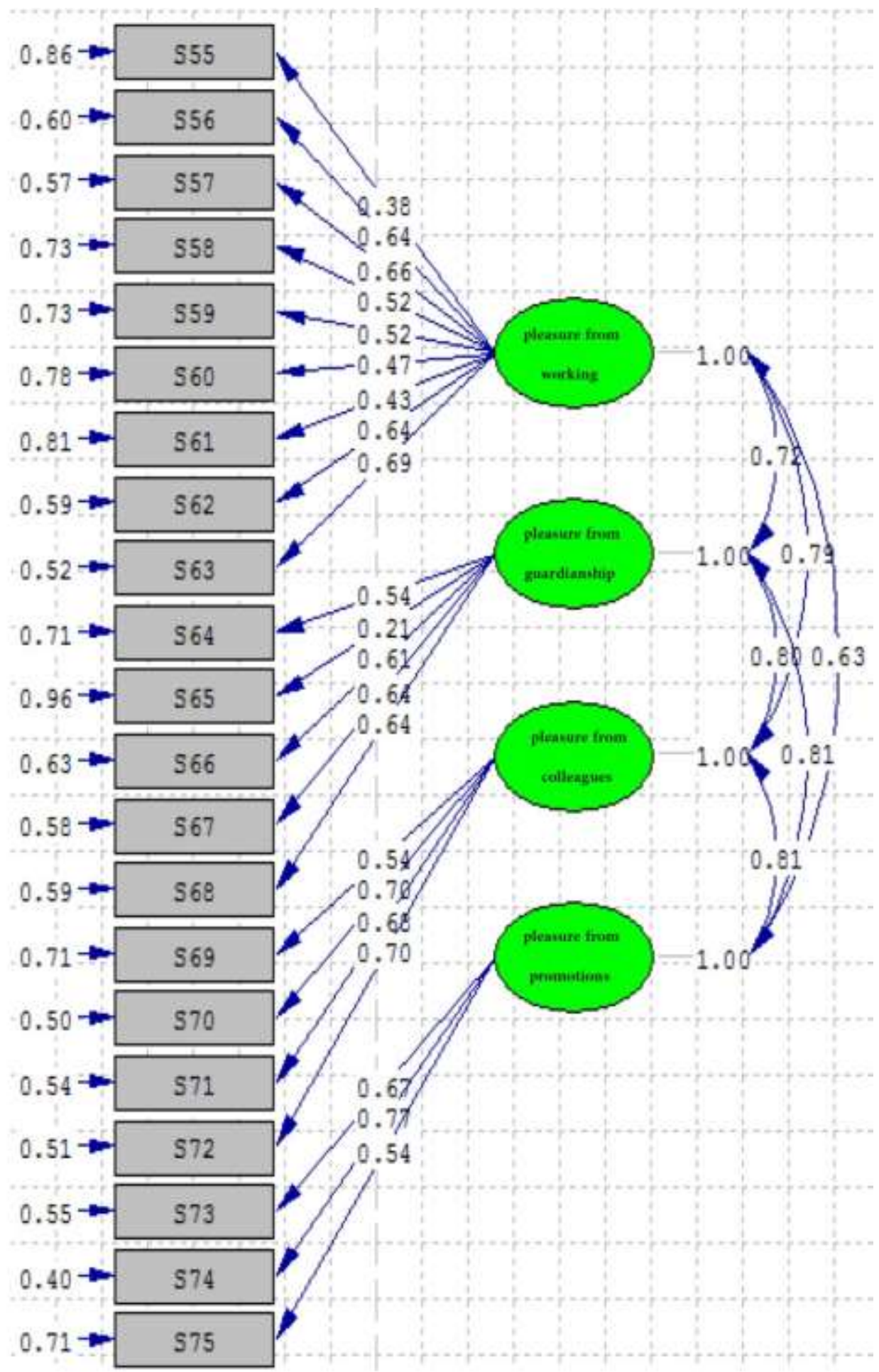

Figure 2: Approval factorial analyses of the components of envy management 
Also, the sig level for relationship between variables is as follows:

Table 1: Obtained values from the final model of the study

\begin{tabular}{|l|l|l|l|l|l|l|}
\hline $\begin{array}{l}\text { Relationship between concepts and } \\
\text { indexes in the model }\end{array}$ & $\begin{array}{l}\text { Standardized } \\
\text { value }\end{array}$ & $\begin{array}{l}\text { Standard } \\
\text { error }\end{array}$ & $\mathrm{t}$-value & $\mathrm{R} 2$ & $\begin{array}{l}\text { Sig } \\
\text { level }\end{array}$ & Result \\
\hline $\begin{array}{l}\text { Organizational climate has a } \\
\text { significant effect on effective } \\
\text { communication }\end{array}$ & 0.89 & 0.13 & 6.88 & 0.8 & $\mathrm{P}<0.01$ & $\begin{array}{l}\text { Hypothesis } \\
\text { approved }\end{array}$ \\
\hline $\begin{array}{l}\text { Effective communications have } \\
\text { significant effect on envy } \\
\text { management }\end{array}$ & 0.09 & 0.045 & 2.01 & 0.71 & $\mathrm{P}<0.05$ & $\begin{array}{l}\text { Hypothesis } \\
\text { approved }\end{array}$ \\
\hline $\begin{array}{l}\text { Spiritual leadership has a } \\
\text { significant effect on professional } \\
\text { development }\end{array}$ & 0.25 & 0.12 & 2.13 & 0.049 & $\mathrm{P}<0.05$ & $\begin{array}{l}\text { Hypothesis } \\
\text { approved }\end{array}$ \\
\hline $\begin{array}{l}\text { Professional development has a } \\
\text { significant effect on job } \\
\text { satisfaction. }\end{array}$ & 0.56 & 0.12 & 4.75 & .320 & $\mathrm{P}<0.01$ & $\begin{array}{l}\text { Hypothesis } \\
\text { approved }\end{array}$ \\
\hline $\begin{array}{l}\text { Job satisfaction has a significant } \\
\text { effect on envy management. }\end{array}$ & 0.83 & 0.097 & 8.54 & .710 & $\mathrm{P}<0.01$ & $\begin{array}{l}\text { Hypothesis } \\
\text { approved }\end{array}$ \\
\hline $\begin{array}{l}\text { Effective communications have } \\
\text { significant effect on professional } \\
\text { development. }\end{array}$ & $0.05-$ & 0.11 & $.43-0$ & 0.049 & $\mathrm{P}>0.05$ & $\begin{array}{l}\text { Hypothesis } \\
\text { approved }\end{array}$ \\
\hline
\end{tabular}

\begin{tabular}{|c|c|c|c|c|c|}
\hline \multirow[t]{2}{*}{ General effect } & \multirow[t]{2}{*}{ Indirect impact } & \multirow{2}{*}{$\begin{array}{l}\text { Direct } \\
\text { impact }\end{array}$} & \multirow{2}{*}{$\begin{array}{c}\text { Intermediate } \\
\text { variables }\end{array}$} & \multicolumn{2}{|r|}{ Variable } \\
\hline & & & & Influenced & Influential \\
\hline 0.08 & $(0.09) *(0.89)$ & --- & $\begin{array}{r}\text { Effective } \\
\text { communications }\end{array}$ & $\begin{array}{r}\text { Envy } \\
\text { management }\end{array}$ & $\begin{array}{r}\text { Organizational } \\
\text { climate }\end{array}$ \\
\hline 0.12 & $(0.83) *(0.56) *(0.25)$ & --- & $\begin{array}{l}\text { Professional } \\
\text { development and } \\
\text { job satisfaction }\end{array}$ & $\begin{array}{r}\text { Envy } \\
\text { management }\end{array}$ & $\begin{array}{l}\text { Spiritual } \\
\text { leadership }\end{array}$ \\
\hline
\end{tabular}

The value of standard estimation of factorial loads was calculated by maximum likelihood method that is shown in the figure 2 .

These values that are so-called $\lambda$, are used for estimating the standard of latent variable scores in the analysis of structural equation modeling and these values are comparable. Also, values of estimating standard error showed the rate of error in estimating factorial loads that smaller values (close to 0 ) represent more precise estimations and smaller confident interval. The values of significant level that are the result of dividing estimating factorial load on standard error, that shows significance of estimating factorial load (significant difference of factorial load with zero). The values of significant level between 1.96 and 1.96 showed lack of the significant impact between related latent variables. Values of the significant level that is equal and greater than 3 showed the sig level with more than 99\% confident between latent variables. Therefore, as seen in the columns of significant level, the effect of variables on each other approved with more than $99 \%$. Finally, the column of specified variance shows the value of specified variance of relationship between latent variables. The more values to the level of 1 showed more appropriateness of relationships between research variables. regarding indirect relationship between research variables it was observed that in analyzing indirect relationship of organizational climate on envy management, the variable of spiritual leadership via the variable of effective communications has less effects (0.08) on envy management against variables of professional development and job satisfaction (Eta effect of 0.12). 


\section{Fitting the research model}

Fitting model means that the observed matrix of variance-covariance or predicted matrix of variance-covariance by the model should have close values or so-called they should have fitting. To the extent that our values in the two matrixes are closer to each other, the model has more fitting. In the structural equation modelling it is possible to trust model estimations that has sufficient fitting.

Table 2: Fitting indexes of the final model

\begin{tabular}{|c|c|c|c|}
\hline Index title & Accepted domain & Value & Result \\
\hline $\mathrm{X}^{2} / \mathrm{df}$ & $\mathrm{X} 2 / \mathrm{df} \leq 3$ & 2.85 & Model approved \\
\hline RMSEA & RMSEA $<0.09$ & 0.076 & Model approved \\
\hline GFI & GFI $>0.9$ & 0.91 & Model approved \\
\hline AGFI & AGFI $>0.85$ & 0.86 & Model approved \\
\hline CFI & CFI $>0.90$ & 0.92 & Model approved \\
\hline IFI & IFI $>0.90$ & 0.92 & Model approved \\
\hline
\end{tabular}

After estimating parameters of the model, the question is that to what extent the specified model are in line with related data? Answer to this question is possible only through analyzing the fitting model. Therefore, in analysis of structural modeling the researcher after estimating parameters and before interpreting them, should ensure about fitting of the model. For this reason, by fitting model we mean the extent in which a model is agreeable and compatible with related data. Therefore, the comparative fit index is calculated. This index with respect to appropriateness is similar to correlative coefficient. Both of these criteria are variable from 0 to 1 , though theoretically they might be negative. To the extent that comparative fit index and adjust goodness of fit index is closer to 1 , then goodness of fitting model is more with observed data.

Criteria of Root Mean Square Error of Approximation (RMSEA) as the size of difference are defined for every degree of freedom. Root Mean Square Error of Approximation that is the same test of deviating from degree of freedom for models with a good fitting is less than 0.05 . Greater values to 0.08 showed a reasonable error for approximation in the society. Models which their RMSEA is 0.1 and greater have a weak fitting.

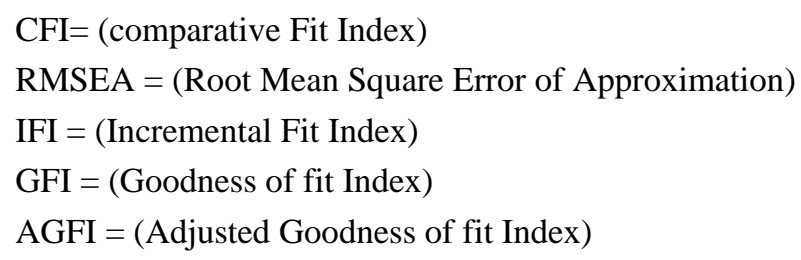

The entire applied fitting indexes showed that this model has a good fitting. Therefore, we conclude that the research model has a high ability for measuring the main research variables. According to standardization of the model LIZEREL findings are trustable.

Testing research hypotheses using structural equation modeling

According to table $(1,2)$ result of analyzing the research questions using results of structural equation modeling are as follows:

First hypothesis: Organizational climate has a significant effect on effective communication. 
According to standard estimation of the variable of organizational climate on effective communication that is 0.89 and values of $\mathrm{T}=6.88$ and $\mathrm{R} 2=0.8$ we can conclude that in the sig level $\mathrm{P}<0.01$, organizational climate has a significant effect on effective communications. Therefore the research hypothesis is approved.

Second hypothesis: Effective communications have significant effect on envy management.

According to standard estimation of the variable of Effective communications on Effective communications that is 0.09 and values of $\mathrm{T}=2.01$ and $\mathrm{R}^{2}=0.71$ we can conclude that in the sig level $\mathrm{P}<0.01$, Effective communications has a significant effect on Effective communications. Therefore, the research hypothesis was approved.

Third hypothesis: Spiritual leadership has a significant effect on professional development.

According to standard estimation of the variable of Spiritual leadership on professional development that is 0.25 and values of $\mathrm{T}=2.13$ and $\mathrm{R} 2=0.049$ we can conclude that in the sig level $\mathrm{P}<0.05$, Spiritual leadership has a significant effect on professional development. Therefore, the research hypothesis was approved.

Fourth hypothesis: Professional development has a significant effect on job satisfaction.

According to standard estimation of the variable of Professional development on job satisfaction that is 0.56 and values of $T=4.75$ and $R 2=0.32$ we can conclude that in the sig level $\mathrm{P}<0.01$, Professional development has a significant effect on job satisfaction. Therefore, the research hypothesis was approved.

Fifth hypothesis: Job satisfaction has a significant effect on envy management.

According to standard estimation of the variable of job satisfaction on envy management that is 0.83 and values of $T=8.54$ and $R 2=0.71$ we can conclude that in the sig level $\mathrm{P}<0.01$, job satisfaction has a significant effect on envy management. Therefore, the research hypothesis was approved.

Sixth hypothesis: Effective communications have significant effect on professional development.

According to standard estimation of the variable of Effective communications on professional development that is -0.05 and values of $\mathrm{T}=-0.43$ and $\mathrm{R} 2=0.049$ we can conclude that in the sig level $\mathrm{P}>0.05$, Effective communications has not any significant effect on professional development. Therefore, the research hypothesis was not approved.

As well the significant level of relationship between variables is as follows: 


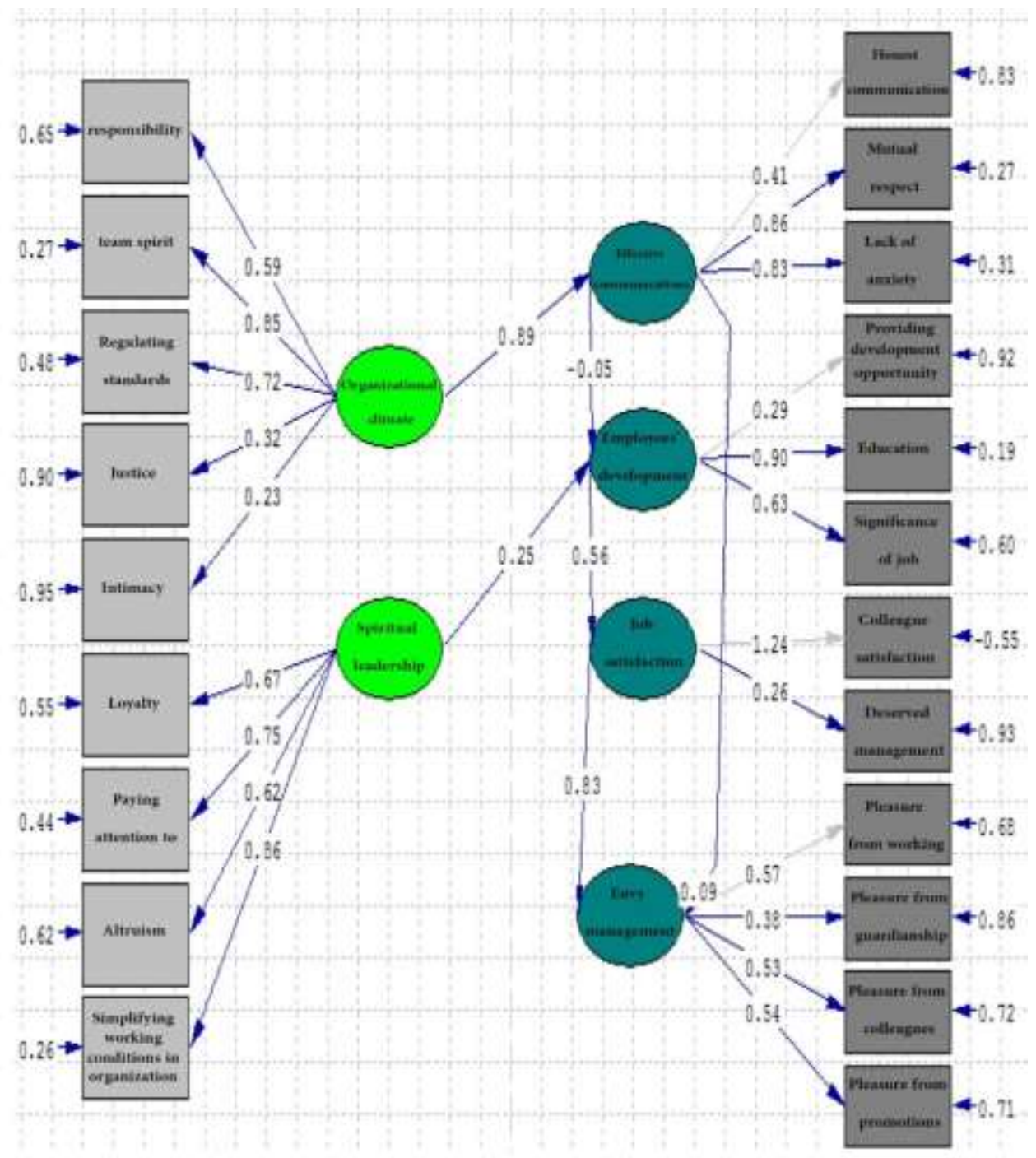

Figure 3: The final model of the study 


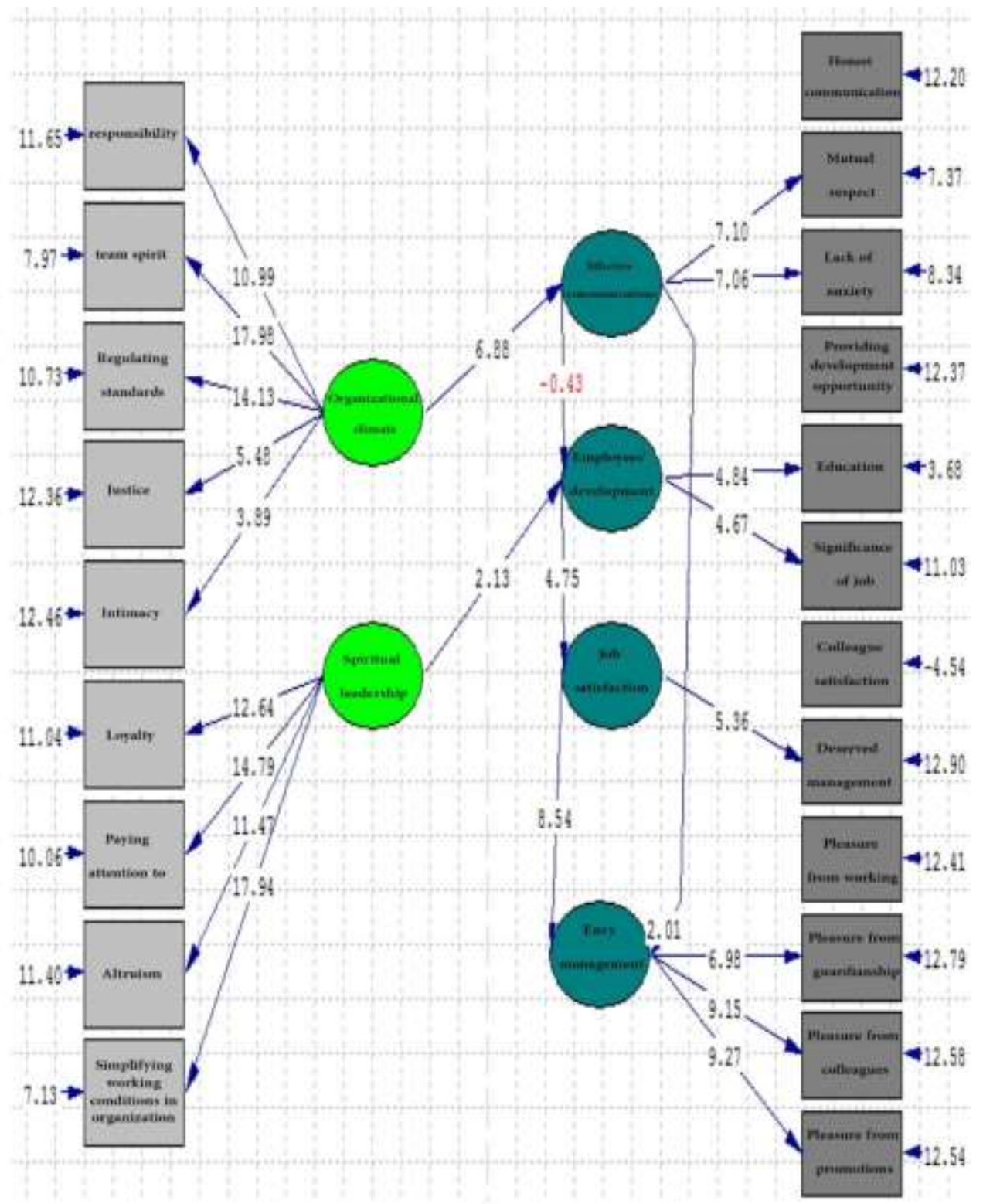

Figure 4: Significant level of relationship between variables

\section{DISCUSSION AND CONCLUSION}

Result obtained from the primary research pattern shows that expect the direct impact of effective communications on professional development faculty members, other relations and effects between variables are significant and we can say that the significant relationship between variables of spiritual leadership and organizational climate, employees' development and effective communication and finally controlling envy is at $95 \%$ level of confidence. Comparing the indirect relationship between organizational climate and 
management of envy, spiritual leadership through the effective communication is less influential on management of envy to professional development and job satisfaction.

According to findings, there is a positive and significant relationship between job satisfaction and faculty's professional development and effective communication so that there is a significant direct effectiveness between organizational climate and effective communication. Regarding, findings of the research which were approved by the studies done by Hariri et al. (2013), Vaziri,Shirzadi Esfahani (2010), Liman (2003), Eskandari et al. (2010), job satisfaction is one of the concepts usually proposed to develop human resources. Many employees, who are more commitment to the organization, try to find out their competence and abilities in an optimal way. Good employees tend to be better and to this end they attempt to catch opportunities by which to be trained and developed and finally promoted in their position. When an organization offers programs for employees' development and promotion and invest to this end, employees attempt to gain opportunities for their development and promotion (Abol A'laei, 2015). If organizational climate is not optimal for employees, envy will be substituted with empathy and it results in enemy among individuals and humanism will be lessened among the members (Salovey,Rodin, 1984). However, appropriate organizational climate creates confidence and effective communication among faculty members that leads to commitment and satisfaction in members. And the most important that the appropriate organizational climate help them to be developed and control their envy.

Furthermore, the effect of spiritual leadership on management of envy through the variables like professional development and job satisfaction which was more influential on final model indicates of this fact that spiritual leadership role is stimulating employees with high proficiency, capable, and commitment and motivation by applying spiritual view point and creating cultural backgrounds based on the human values (Strak et al., 2008). These findings were approved by research findings done by Vahed Chokade and Kazempur (2015), Erdil, Muceldili (2014), Khalifeh (2012), Odle (2014), Nandedkar (2011); and this variable intensely reduces employees' envy who have professional development and high job satisfaction. Thus, research findings in which the theory of spiritual leadership was considered as an intrinsic motivational model in the previous studied has been founded with features including hope, belief, and humanism (Fernando et al, 2009). In the university it is possible to imagine university managers as spiritual leaders that usually values such as harmony, love and liking, solidarity, peace and tranquilization, honesty and trust, to be able to experience prevention and decreasing envy among faculty members and even employees.

Avolio et al indicated that employees development with is related to leadership and results in commitment to individuals (Shabani Bahar et al., 2013; Avolio et al., 2004).

Also, professional development in professors causes expressing innovation and more creativity (Shaemi Barzaki et al., 2013). Because expression of envy and intensifying it depends on comparison of individual with others and concludes that others, expect their benefits are similar to him. The second is benefits that others acquire and seems inaccessible for the individual (Smith, Kim, 2007) and according to the balance theory of Heider then individual considers himself in the same class as the opposite person there is a strong intension to believe that they should have an equal prosperity and this pressure for equality should be strong to some extent that nature of justice or a "must force" should be considered (Woltfried, 2014). Therefore, faculty members may consider university managers as sensitive, kind, and leader that for development and their job satisfaction they should be active and the thoughts of envy decreases among them. 


\section{Suggestions}

On the basis of findings, envy has very destructive role in development and scientific mentality of faculty members. Therefore, providing a model for management of envy in Islamic University could be helpful in increasing faculty members' commitment. Since there were various kinds of variables in managing faculty members' envy, there are suggestions which are as follow:

It is suggested that to create an optimal organizational climate to reduce and manage organizational envy among sophisticated members of university for the fact that university is a symbol of optimal culture which is out of any moral blackguardism like envy. To this end, professional development workplaces and effective communication should be performed.

According to direct and indirect relationship between spiritual leadership and management of envy, it is offered that spiritual leadership either directly or indirectly could be effective in reducing organizational envy via professional developments and preparing job satisfaction. So it is better to substitute managers with spiritual leadership.

\section{REFERENCES}

[1] Abedi Jafari, H., Shie Zadeh, E-banking , Sayyed Hossain, S.S. (2014). Envy on intention to leave nurse survices to intermediating self-respect and anti-civilization behaviors. The Journal of managing organizational culture, 12 (4): 763-786.

[2] Abolalaei, B. (2015). Quality of workers with motivation and working friendly and organization. Tehran. Publication of Industrial management.

[3] Ahmadi, F, Nasiriani, Kh, Abazari, P. (2008). Delfi Tequnique; an instrument in research, the Iranian journal of Education in medical sciences, spring and summer, 8 (1), 175-185.

[4] Alicke, M. A., Zell, E. (2008). Social comparison and envy. In R. Smith (Ed.), Envy: Theory and research (73-93). Oxford, U.K.: Oxford Press.

[5] Avolio, B. J., Gardner, W. (2005).Leadership Development: Getting to thee Root of Positive Forms of Leadership. The Leadership Quarterly, 16, 315-338.

[6] Baumel,A.,Berant,E .(2015).The role of attachment styles in malicious envy.jounal of Research in personality 55:1-9.

[7] Ben-Ze'ev, A. (1992). Envy and inequality. Journal of Philosophy, 89, 551-581.

[8] Burns, N., Grove, S. (2001). The practice of nursing research. 4th ed. Philadelphia: WB Saunders Co.

[9] Burns, N., Grove, S. (2001). The practice of nursing research. 4th ed. Philadelphia: WB Saunders Co.

[10] Cohen-Charash, Y.,Larson, E. (2011). Ability to change a situation and self-esteem as determinants of constructive and destructive reactions to envy. Paper presented at the Annual Meeting of the Academy of Management, San Antonio, TX.

[11] Cohen-Charash, Y., Mueller, J.S., (2007). Does perceived unfairness exacerbate or mitigate interpersonal counterproductive work behaviors related to envy? Journal of Applied Psychology. 92, 666-680.

[12]Danaei Fard, H. (2011). Applying the research strategy of theoretical foundation in practice: construction of organizational indifference, Imam Sadegh University, Tehran.

[13]DelPriore, D. J., Hill, S. E., \& Buss, D. M. (2011). Envy: Functional specificity and sex- differentiated design features. Personality and Individual Differences, 53, 317 322. 
[14] Duffy, K., Shaw, D.; Schaubroeck, M. (2008). Envy in organization life. In Smith, R. (Ed), Envy: Theory and research, Oxford University Press.

[15] Erdil O ,Muceldili B. (2014) The effects of envy on job engagement and turnover intention .10th International strategic management conference. envy.Journal of research in personality. doctoral dissertation, Bar-Ilan University, Ramat-Gan, Israel.

[16] Erdil O ,Muceldili B. (2014) The effects of envy on job engagement and turnover intention .10th International strategic management conference. envy.Journal of research in personality. doctoral dissertation, Bar-Ilan University, Ramat-Gan, Israel.

[17] Fernando, M., Beale, F., Geroy, G.D.(2009). The Spiritual Dimension in Leadership at Dilmah Tea, Leadership \& Organization Development Journal, 30 6, pp.522-539.

[18]Festinger, L. (1954). A theory of social comparison processes. Human Relations, 7, 117-140.

[19] Foster, G. M. (1972). The anatomy of envy: A study in symbolic behavior. Current Anthropology, 13, 165-186.

[20] Gino, F.,Pierce, L. (2010). Robin Hood under the hood: Wealth-based discrimination in illicit customer help. Organization Science, 21, 1176-1194.

[21] Gino, F., Pierce, L. (2010). Robin Hood under the hood: Wealth-based discrimination in illicit customer help. Organization Science, 21, 1176-1194.

[22] Gol Parvar, M., Javadian, Z., Hosainzadeh, Kh. (2011). Structural pattern of psychological contract, organizational justice, ethical leadership, interaction of leadermember and organizational support. The journal of new issues in organizational and industrial psychology, 2 (7): 21-32.

[23] Golbaf, A. (1996). Envy, the most dangerous national damaging factor. Journal of reporting political sciences, 54-63.

[24] Hariri, N.; Rotan, S.R.; Janmohamadi, M. (2013). Measuring relationship between perceived organizational support and indifference in bookholders. Journal of book holding research and university informative. 47 (4): 397-414.

[25] Heidari, H.; Mosavi, F.; Hasani, S.R. (2014). Designing a structural model of managing human resources for access to organizational loyality. Journal of governmental management, 6 (3): 457-480.

[26] Heider,F. (1958). The psychology of interpersonal relations. Hillsdale,Newjersey

[27] Hodson, R. (2002). Management citizenship behavior and its consequences, work and occupations, Vol .29 No.1 'pp64-96.

[28] Kahrobaei, S., Mortazavi, S. (2015). Analyzing the effect of spiritual leadership on organizational justice via the role of the intermediate of spiritual health. The journal of general management studies, 8

[29] Khalifeh, Y. (2012). Analyzing the relationship between interaction between manageremployee and job satisfaction-MA thesis . Economy University of Semnan.

[30] Kim S, Oneill J, Minche H.(2010). When dose an employee not help coworkers? The effect of leader - member exchange on employee envy and organizational citizenship behavior .International journal of hospitality management.

[31] Layman, O. (2003). creating an excellent environment for working: lessons of one percent higher companies, a collection of 35th of international conference human resources in the managing center of Europe, Veniz-Italy, Translation: Mohamad Ali Babaei Zakliki and Behzad Abi Allaei.

[32] Mir Kamaki, M. (1999). Leadership and educational management. Tehran, Ramin Publication.

[33] Moradi, M.,Sayyed Kalan, S.M. (2015). Professional development of teachers (improving the quality of learning teaching process, Ardebil, Nayab Publication.

[34] Nandedkar, P. (2011). Examining the knowledge sharing and uncivil behaviors of envious employees: an affective events theory perspective, (Doctoral Dissertation). University of Texas- Pan American. 
[35] Odle.Taylor K.(2014) The implication of distance and envy in organizations: an exploration of leader- member exchange and organizational citizenship behaviors. Trace: Tennessee research and creative exchange.

[36] Özkoç, Aziz Gökhan,. Çalışkan, Nurgül.(2015). The Impact of Organizational Envy on Organizational Climate Created among Employees: An Application in Accommodation

[37] Parrott, W.G. (1991). The emotional experiences of envy and jealousy. In: Salovey, P. (Ed.), The psychology of jealousy and envy (pp. 3-30). The Guilford Press, New York, NY.

[38] Ridenour,C.S., Nweman , I.(2008).Mixed methods research: Exploring the interactive continuum.SIU Press.

[39] Sadeghi, A.; Vahed Chokdeh, H.; Kazempour, E. (2013). Relationship between spiritual leadership with enabling in administrative and educational experts of Gilan University, education and developing human resources, 2 (4): 39-53.

[40] Salovey, P. (1991). Social comparison processes in envy and jealousy. In J. Suls \& T.A. Wills (Eds.), Social comparison: Contemporary theory and research (pp. 261285).

[41] Salovey, P.,Rodin, J. (1984). Some antecedents and consequences of socialcomparison jealousy. Journal of Personality and Social Psychology, 47, 780-792.

[42] Schaubroeck, J.,Lam, S. K. (2004). Comparing lots before and after: Promotion rejectees' invidious reactions to promotees. Organizational Behavior and Human Decision Processes, 94, 33-47.

[43] Shaemi- Barzaki, A., Hatampoor, F., Azarkhavarani, RR. (2013). The Relationship of organizational Culture and Staff Empowerment. Journal Health SystRes, 9(6), 630-9. [Persian]

[44] Shirzadi, M. Esfahani, H. (2010). Analyzing the relationship of organizational climate with happiness, livelihood and faculty members of Alzahra University. The journal of new educational thoughts, 6 (2): 173-190.

[45] Smith R. H., Kim S.H. (2007). Comprehending envy" Psychological Bulletin,133: 46:64

[46] Tai, K., Narayanan, J., McAllister, D. J. (2012). Envy as pain: Rethinking the nature of envy and its implications for employees and organizations. Academy of Management Review, 37(1), 107-129.

[47] Tesser, A. (1988). Toward a self-evaluation maintenance model of social behavior. Advances in Experimental Social Psychology, 21, 181-227.

[48] Vecchio, RP.(2000). Negative emotion in the workplace: Employee jealousy and envy. Int J Stress Manag.,p.161-79.

[49] Vecchio, P. (1995). Its not easy being green: Jealousy and Envy in the workplace. Research in Personnel and Human Resourees Management, 13, 201-244.

[50] Vecchio, Robert P.(2000). Negative Emotion in the Workplace:Employee Jealousy and Envy. International Journal of Stress Management, Vol. 7, No. 3, 2000

[51] Weltreid,Sharone.(2014).Reducig Envy and increasing happonessw for another's success.Fctulty of the college of arts and $\mathrm{sC}$ of American University in Partial University in partial Fulfillment of the Requirements fior the Degree Master of Arts in Psychology Chair.

\section{Article history:}

- $\quad$ Received 6 May 2016

- Accepted 15 August 2016 